\title{
Karakteristik Campuran Hot Rolled Sheet Wearing Coarse Yang Menggunakan Batu Dari Buntao' Toraja Utara
}

\author{
Agus Tolla Londongsalu*1, Roy Haryanto Menge ${ }^{* 2}$, Alpius ${ }^{\star 3}$, Benyamin Tanan ${ }^{* 4}$ \\ *1,2 Mahasiswa Prodi Teknik Sipil, Universitas Kristen Indonesia Paulus, Makassar, Indonesia \\ agustollalondongsalu@gmail.com,royharyanto161@gmail.com \\ *3,4 Dosen Prodi Teknik Sipil, Universitas Kristen Indonesia Paulus, Dosen Teknik Sipil, Makassar, Indonesia \\ nyamintan2002@yahoo.com , alpiusnini@gmail.com
}

\begin{abstract}
ABSTRAK
Penggunaan batu gunung dari Desa Buntao' masih terbatas untuk pondasi bangunan serta pasangan talut dan belum dimanfaatkan sebagai bahan dasar lapisan tipis aspal beton (LATASTON). Tujuan dari penelitian ini adalah mengetahui karakteristik batu gunung dari Desa Buntao' sebagai komposisi campuran perkerasan LATASTON HRS-WC gradasi senjang dan semi senjang, dan mengetahui karakteristik Marshall, serta Indeks Kekuatan Sisa pada campuran tersebut. Metode penelitian melalui penelitian laboratorium yaitu pengujian Marshall. Hasil pengujian marshall diperoleh nilai karakteristik Marshall campuran LATASTON HRS-WC Gradasi Senjang dan Semi Senjang yaitu nilai VIM sebesar 5,62\% (Senjang) dan $5,63 \%$ (Semi Senjang), nilai Stabilitas sebesar 1680,29 kg (Senjang) dan 1347,92 kg (Semi Senjang), nilai VMA sebesar $18,03 \%$ (Senjang) dan 18,14\% (Semi Senjang) dan nilai flow sebesar 4,70 mm (Senjang) dan 4,40 mm (Semi Senjang) serta Kadar Aspal 7,6\% (Senjang) dan 7,6\% (Semi Senjang). Untuk nilai Indeks Kekuatan Sisa (Indeks Perendaman) dari hasil pengujian Marshall Immersion sebesar 93.73 \% untuk Senjang, dan 97,48\% untuk Semi Senjang.
\end{abstract}

Kata Kunci : Batu Gunung Buntao; LATASTON HRS-WC; Karakteristik Marshall

\begin{abstract}
The use of mountain rocks from Buntao Village is still limited to building foundations and talut pairs and has not been used as a base for thin concrete asphalt (LATASTON). The purpose of this study was to determine the characteristics of mountain rocks from Buntao 'Village as a mixture of pavement composition HRS-WC LATASTON in gap graded and semi-gap graded, and to know the Marshall characteristics, as well as the Strength Index Remaining in the mixture. The research method is through laboratory research namely Marshall testing. Marshall test results obtained Marshall characteristics mix of HRS-WC LATASTON gap graded and semi gap graded VIM values of $5.62 \%$ (gap graded) and $5.63 \%$ (semi gap graded), stability values of 1680.29 $\mathrm{kg}$ (gap graded) and $1347,92 \mathrm{~kg}$ (semi gap graded) VMA value of $18.03 \%$ (gap graded) and $18.14 \%$ (semi gap graded) and flow values of $4.70 \mathrm{~mm}$ (gap graded) and $4.40 \mathrm{~mm}$ (semi gap graded) and asphalt Levels $7.6 \%$ (gap graded) and $7.6 \%$ (semi gap graded). For the residual strength index value (immersion Index) from the Marshall Immersion test results of $93.73 \%$ for gap graded, and $97.48 \%$ for semi gap graded.
\end{abstract}

Keywords: Mount Buntao Stone; HRS-WC LATASTON; Marshall characteristics

\section{PENDAHULUAN}

Pembangunan prasarana jalan di Kabupaten Toraja Utara Provinsi Sulawesi Selatan pada umumnya masih menggunakan material yang didatangkan dari luar kabupaten. Sebagian material didatangkan dari Tapparan Kabupaten Tana Toraja dan sebagian Lainnya didatangkan dari Kota Palopo khususnya untuk perkerasan beraspal. Desa Buntao' Kecamatan Buntao' yang merupakan wilayah Kabupaten Toraja Utara merupakan daerah yang memiliki sumber material berupa batu gunung yang belum dimanfaatkan secara maksimal sampai saat ini, batu gunung dari Desa Buntao' hanya dimanfaatkan sebagai bahan pondasi bangunan atau pasangan talut. Penggunaan material batu gunung dari Desa Buntao' di Kabupaten Toraja Utara yang selama ini kurang dimanfaatkan juga didasari oleh faktor belum adanya penelitian tentang bagaimana karasteristik material tersebut, sehingga baik atau buruknya kualitas material belum diketahui oleh Pemerintah setempat. Untuk memaksimalkan pemanfaatan batu gunung dari Desa Buntao', perlu dilakukan penelitian apakah material tersebut dapat memenuhi spesifikasi 
Bina Marga untuk dijadikan bahan perkerasan jalan khususnya untuk lapis perkerasan beraspal. Tujuan dari penelitian ini adalah mengetahui karakteristik agregat Desa Buntao', menentukan komposisi campuran HRS-WC yang menggunakan agregat dari Desa Buntao', mengetahui karakteristik Marshall, dan Indeks Kekuatan Sisa campuran HRS-WC yang menggunakan agregat dari Desa Buntao'.

\section{Rancangan Campuran HRS - WC (Mix Design HRS)}

Komposisi rancangan campuran didasarkan pada gradasi campuran agregat yang dipilih. Dimana ukuran dari setiap agregat didasarkan pada standar Petunjuk Pelaksanaan Lapis HRS (LATASTON) [1].

Tabel 1. Gradasi agregat untuk campuran Lataston HRS-WC

\begin{tabular}{ccc}
\hline $\begin{array}{c}\text { Ukuran } \\
\text { Ayakan }\end{array}$ & $\begin{array}{c}\text { \% Berat Lolos Terhadap Total Agregat dalam } \\
\text { Campuran } \\
\text { Lataston (HRS-WC) }\end{array}$ \\
\cline { 2 - 3 } & Senjang & Semi Senjang \\
\hline 37.5 & & 100 \\
25 & 100 & $87-100$ \\
19 & $90-100$ & $55-88$ \\
12.5 & $75-85$ & $50-62$ \\
9.5 & $50-72$ & \\
4.75 & $35-60$ & $20-45$ \\
2.36 & & $15-35$ \\
1.18 & & $6-10$ \\
0.600 & $6-10$ & \\
0.300 & & \\
0.150 & & \\
0.075 & &
\end{tabular}

\section{Pengujian Karakteristik Campuran HRS-WC}

Salah satu hal yang cukup berpengaruh terhdap karakteristik HRS adalah rancangan campuran, baik itu pada saat pencampuran, penghampran, pemadatan, atau pada saat pemanfaatannya. Suatau rancangan campuran dengan proporsi tertentu akan menghasilkan karakteritik campuran tertentu pula.

\section{Pemeriksaan Marshall Konvensional}

Kinerja campuran HRS dapat diperiksa dengan alat pemeriksaan Marshall.Pemeriksaan ini pertama kali dikenalkan oleh Bruce Marshall, selanjutnya dikembangkan oleh U.S. Corps of Engineer. Alat Marshall merupakan alat tekan yang dilengkapi dengan proving ring (cincin penguji) yang berkapasitas $2500 \mathrm{~kg}$ atau 5000 pound. Proving ring dilengkapi dengan arloji pengukur yang berguna untuk mengukur stabilitas campuran, di samping itu terdapat arloji kelelehan (flow meter) untuk mengukur kelelehan plastis (flow) [1].

Pengujian Marshall (Marshall Test) adalah suatu metode pengujian untuk mengetahui nilai ketahanan (stabilitas) dan kelelehan Plastis (flow) campuran beraspal.Ketahanan adalah kemampuan menerima beban sampai terjadi kelelehan plastis, dinyatakan dalam satuan kilogram atau pound. Dengan kata lain stabilitas Marshall dimaksudkan sebagai beban maksimum yang dapat diterima oleh campuran sebelum runtuh. Sedangkan kelelehan plastis adalah perubahan bentuk campuran aspal yang terjadi akibat suatu beban hingga batas runtuh, yang dinyatakan dalam satuan kilogram atau pound. Sebelum pengujian Marshall terlebih dahulu dilakukan proses perendaman benda uji. Proses perendaman benda uji dilakukan pada suhu $60^{\circ} \mathrm{C}$ selama 30-45 menit dan 24 jam dan melakukan pengujian Marshall untuk mengetahui sifat mekanik benda uji yaitu stabilitas dan flow.

Dari proses pemeriksaan dengan alat Marshall untuk campuran HRS, diperoleh data-data berat volume, dinyatakan dalam ton $/ \mathrm{m}^{3}$, stabilitas, dinyatakan dalam kg. Stabilitas menunjukkan kekuatan, ketahanan terhadap terjadinya alur (ruting), kelelehan plastis (flow), dinyatakan dalam $\mathrm{mm}$ atau 0,01 ". Flow merupakan indikator terhadap lentur, dan kadar aspal optimum, dinyatakan dalam \%. 
Tabel 2 : Ketentuan sifat-sifat campuran Lataston

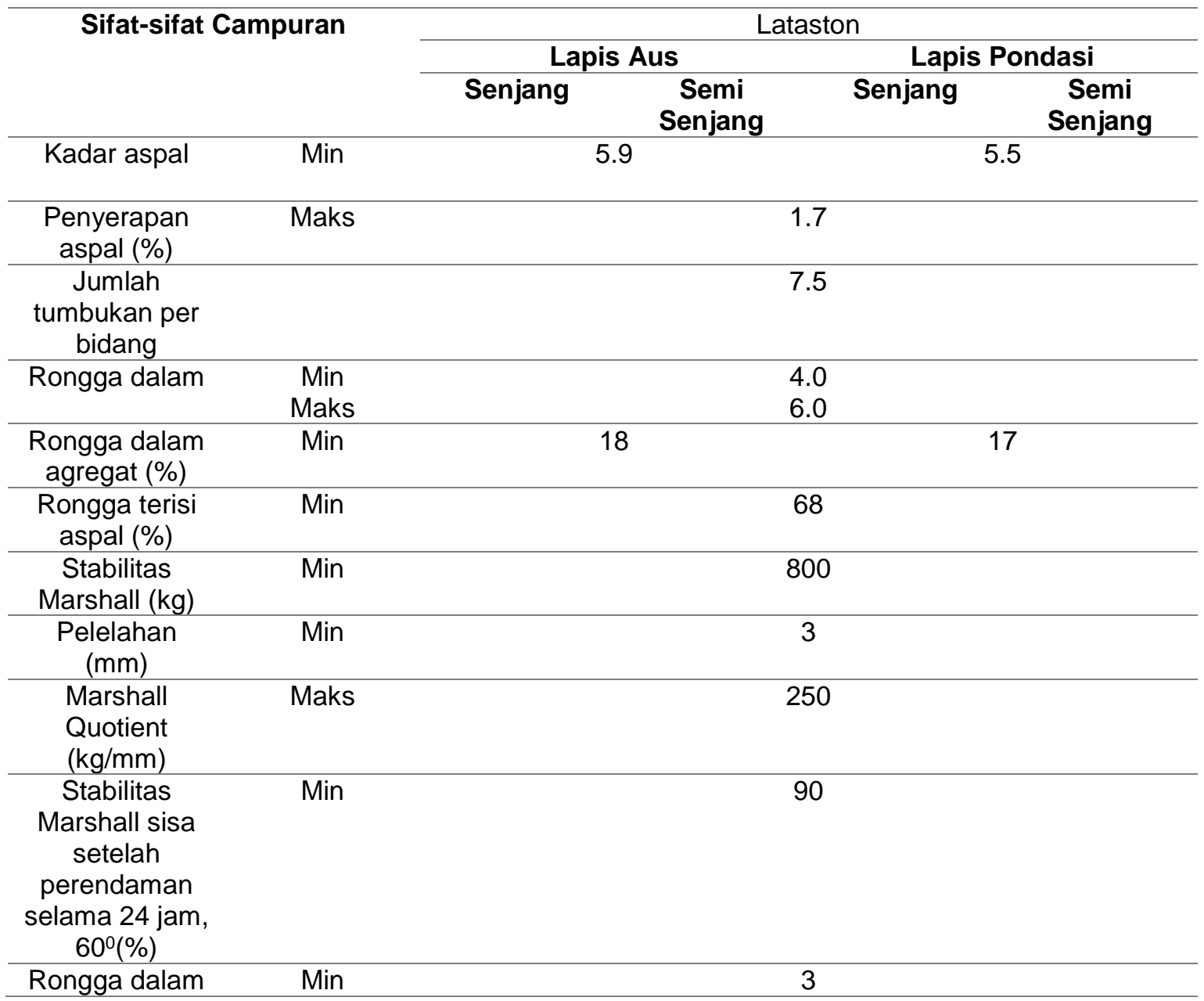

\section{Pemeriksaan Marshall Immertion}

Maksud dari pemeriksaan ini adalah untuk membandingkan nilai stabilitas antara campuran yang dipanaskan selama 30 menit dengan nilai stabilitas campuran HRS yang direndam selam 24 jam dengan suhu $60^{\circ} \mathrm{C}$. Nilai perbandingan harus lebih besar dari $90 \%$ [1].

\section{Penelitian Terdahulu}

Pengujian karakteristik Marshall HRS Base menggunakan slag nikel untuk semi senjang menghasilkan adanya peningkatan stabilitas hingga $6,35 \%$ dan menurunkan nilai flow pada kadar aspal $5,93 \%$ dan $6,35 \%$ dari total bitumen yang digunakan [2].

Kinerja campuran HRS WC dengan filler abu ampas debu menghasilkan hasil uji berat jenis agregat 2,54 $\mathrm{g} / \mathrm{cm}^{3}$, berat jenis SSD $2,57 \mathrm{~g} / \mathrm{cm} 3$, penyerapan $1,2 \%$, abrasi $34,8 \%$, berat jenis spesifik agregat halus $2,5 \mathrm{~g} / \mathrm{cm}^{3}$, berat jenis SSD $2,55 \mathrm{~g} / \mathrm{cm}^{3}$, penyerapan 1,63\%, kadar aspal optimum 7,2\%, uji Marshall MQ $319,22 \mathrm{~kg} / \mathrm{mm}$, VIM 5,31\%, VMA $18,67 \%$, dan VFB $72,03 \%$ [3].
Kinerja modulus resilien dan deformasi permanen dari campuran lataston gradasi senjang dengan bahan aspal modifikasi starbit E-55 menghasilkan peningkatan nilai dibandingkan dengan aspal pen $60 / 70$, dimana peningkatan terjadi sebesar $10 \%, 6 \%$, dan $37,5 \%$. Ketahanan deformasi lebih baik dibandingkan aspal pen 60/70 [4].

Dalam kajian perbedaan kinerja campuran beraspal panas antara jenis lapis tipis aspal beton lapis aus bergradasi senjang dengan yang bergradasi semi senjang menghasilkan kadar aspal terbaik untuk gradasi senjang $7,4 \%$ dan semi senjang $7,2 \%$, untuk stabilitas, VIM, MQ, flow, VMA, dan VFB dari gradasi senjang lebih rendah dibandingkan semi senjang [5].

Dalam studi perilaku campuran lataston dengan limbah karet ban luar sebagai bahan pengganti sebagian aspal menghasilkan nilai stabilitas $1220 \mathrm{~kg}$, $\mathrm{MQ} 7,2 \mathrm{kN} / \mathrm{mm}[6]$.

Dalam campuran HRS dengan material piropilit sebagai filler yang tahan hujan asam menghasilkan polusi udara yang terjadi di Kota Surabaya masih aman dan tidak berpengaruh terhadap nilai stabilitas dan durabilitas dari campuran HRS [7]. 


\section{METODOLOGI PENELITIAN}

Lokasi pengambilan material di Desa Buntao' Kabupaten Toraja. Lokasi pengambilan material dapat dilihat pada Gambar 1. Penelitian ini adalah serangkaian pengujian di laboratorium yang melalui beberapa tahapan, yaitu pemeriksaan karakteristik agregat, pemeriksaan karakteristik aspal, pemeriksaan spesifikasi, rancangan komposisi campuran HRS-WC gradasi senjang dan semi senjang, pembuatan benda uji HRS-WC, Uji Marshall konvensional, penentuan kadar aspal optimum, pembuatan benda uji, dan pengujian Marshall Immertion, dilanjutkan dengan tahap analisis. Bagan alir penelitian disajikan pada Gambar 2.

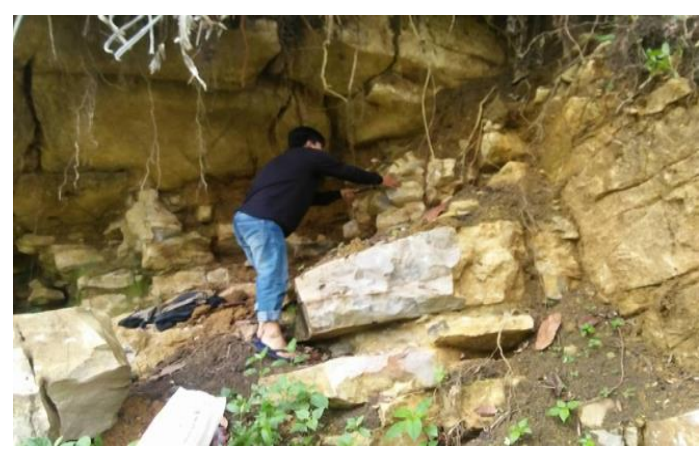

Gambar 1. Lokasi pengambilan material

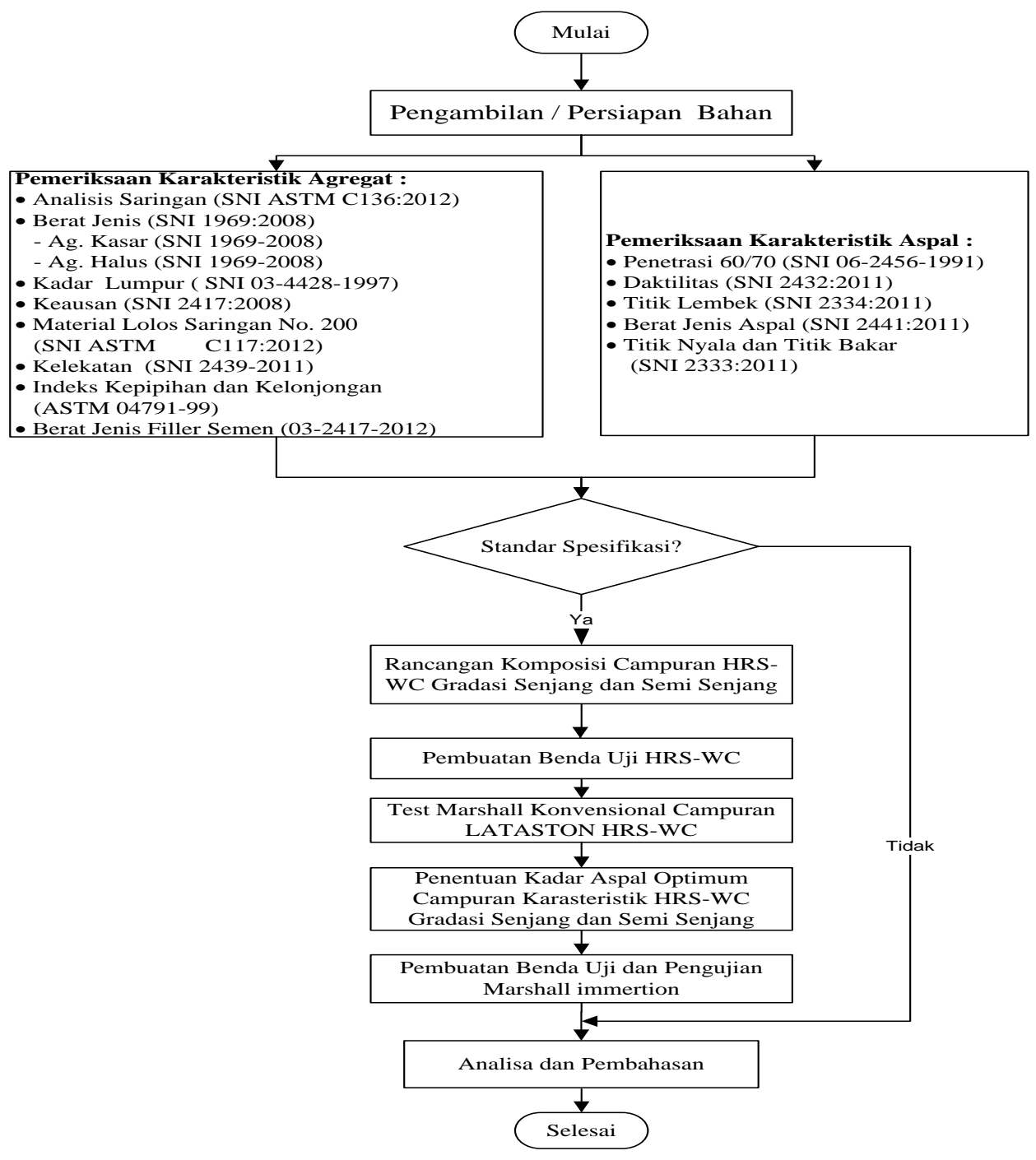

Gambar 2 : Bagan alir penelitian 


\section{HASIL DAN PEMBAHASAN}

\section{Karakteristik dan Analisis Marshall Konvensional Campuran HRS-WC Gradasi Senjang dan Semi Senjang}

\section{a. Analisis Terhadap VIM (Void in Mix)}

Dengan menggunakan kadar Aspal 5,90\% - 7,60\% diperoleh nilai VIM antara 3.98 - 5,57 untuk Gradasi senjang dan 3.98 - 5,58 untuk semi senjang. Nilai VIM dengan kadar Aspal 5,9\%, 6,33\%, 6,75\%, 7,18, dan 7,6\% memenuhi persyaratan [8]. Semakin tinggi kadar aspal yang digunakan maka nilai VIM akan semakin kecil (berkurang) karena kadar aspal yang tinggi akan mengisi rongga-rongga dalam campuran sehingga rongga yang tidak terisi aspal (VIM) semakin berkurang. Grafik VIM gradasi senjang dan semi senjang dapat dilihat pada Gambar 3 dan 4.

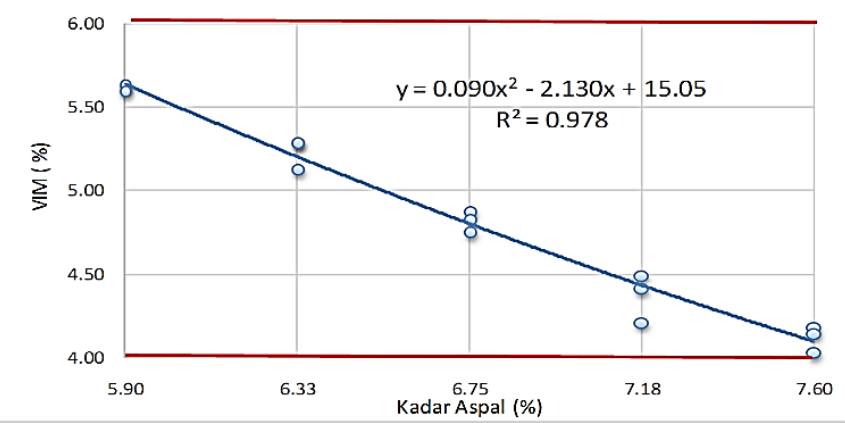

Gambar 3. Grafik VIM gradasi senjang

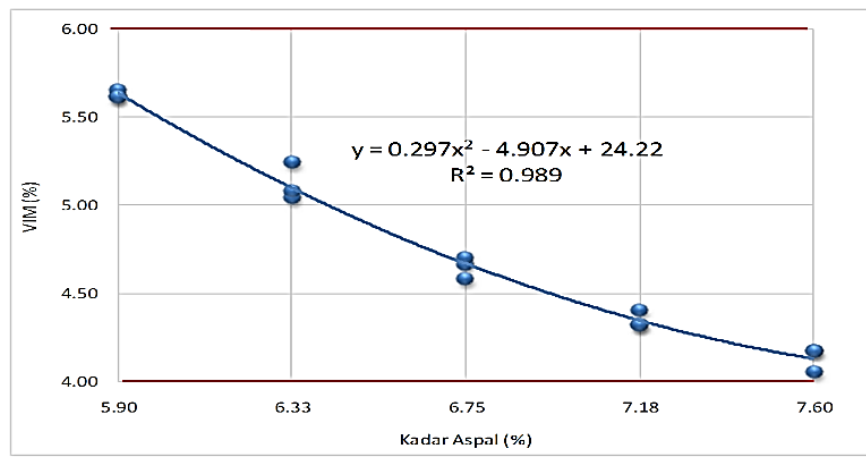

Gambar 4. Grafik VIM gradasi semi senjang

\section{b. Analisis Terhadap Stabilitas}

Dengan menggunakan kadar Aspal 5,90\% - 7,60\% diperoleh nilai Stabilitas antara 1107,88 - 1828 gradasi senjang dan 1200,21 - 1624,89 untuk semi senjang. Semua nilai Stabilitas gradasi senjang dengan kadar Aspal 5,9\%, 6,33\%, 6,75\%, 7,18, dan $7,6 \%$ memenuhi persyaratan [12]. Stabilitas mencapai nilai maksimum pada kadar aspal $6.33 \%$ untuk gradasi senjang dan 6,75 \%. Penambahan kadar aspal selanjutnya menyebabkan nilai stababilitas semakin menurun. Hal ini disebabkan kadar aspal yang tinggi akan mengakibatkan selimut aspal semakin tebal sehingga mengurangi ikatan antar agregat dan menurunkan kekuatan/stabilitas campuran. Grafik stabilitas gradasi senjang dan semi senjang dilihat pada Gambar 5 dan 6 .

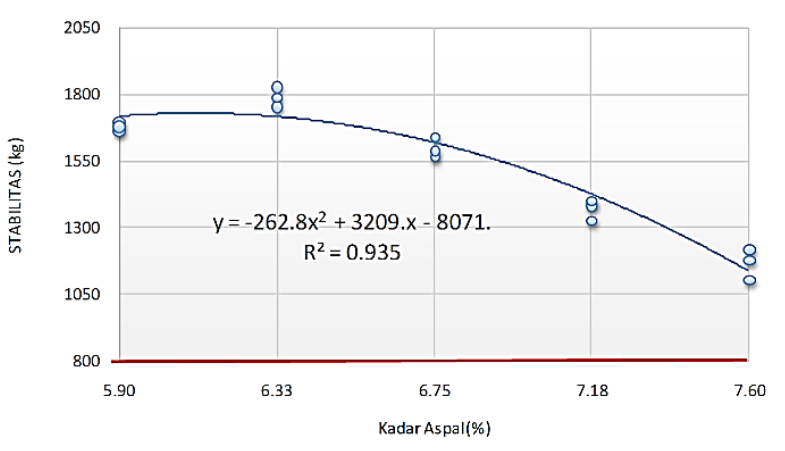

Gambar 5. Grafik stabilitas gradasi senjang

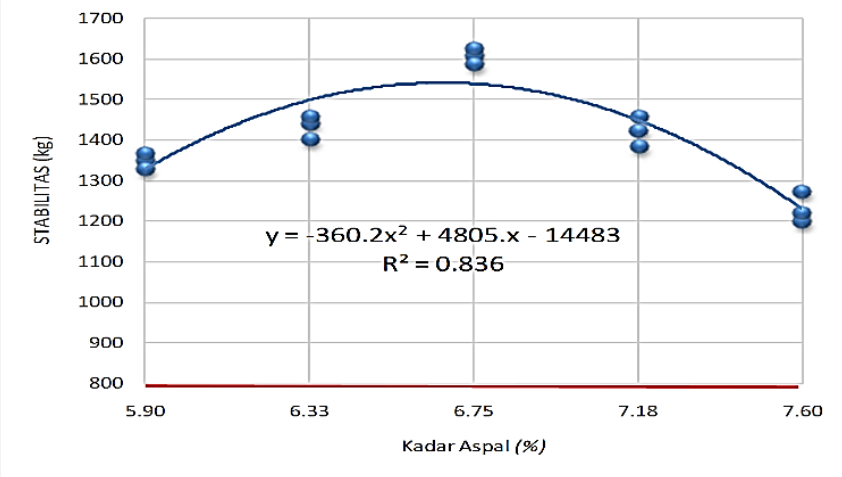

Gambar 6. Grafik stabilitas gradasi semi senjang

\section{c. Analisis Terhadap Flow}

Dengan menggunakan kadar Aspal 5,90\% - 7,60\% diperoleh nilai Flow antara 3.50 - 4,90 untuk gradasi senjang dan 3,05 - 4,50 untuk semi senjang. Semua nilai Flow gradasi senjang dengan kadar aspal 5,90\%, 6,33\%, 6,75\%, 7,18, dan 7,6\% memenuhi persyaratan [8]. Semakin besar kadar aspal yang digunakan akan menurunkan nilai flow sampai pada kadar aspal 6,75\% untuk gradasi senjang dan semi senjang, tetapi jika kadar aspal bertambah lagi maka nilai flow meningkat. Hal ini di sebabkan semakin tinggi kadar aspal membuat agregat terselimuti dengan baik sehingga flow menurun tetapi jika bertambah lagi maka selimut aspal semakin tebal sehingga kelenturan (flow) meningkat. Grafik flow gradasi senjang dan semi senjang dapat dilihat pada Gambar 7 dan 8.

\section{d. Analisis terhadap MQ (Marshall Quotient)}

Dengan menggunakan kadar Aspal 5,90\% - 7,60\% diperoleh nilai MQ antara 256,90 - 487,90 untuk gradasi senjang dan 272,77 - 518,20 untuk semi senjang. Semua nilai $\mathrm{MQ}$ gradasi senjang dengan kadar aspal 5,90\%, 6,33\%, 6,75\%, 7,18\% dan $7,18 \%$ memenuhi persyaratan [8]. Semakin besar 
kadar aspal yang digunakan akan meningkatkan nilai MQ sampai pada kadar aspal 6,75\% dari total kadar aspal yang di gunakan, tetapi jika kadar aspal bertambah lagi maka nilai $\mathrm{MQ}$ menurun. Hal ini di sebabkan semakin tinggi kadar aspal akan berakibat berkurangnya ikatan antar agregat sehingga menurunkan kekuatan/stabilitas dan membuat selimut aspal semakin tebal sehingga kelenturan (flow) meningkat. Grafik $\mathrm{MQ}$ gradasi senjang dan semi senjang disajikan pada Gambar 9 dan 10.

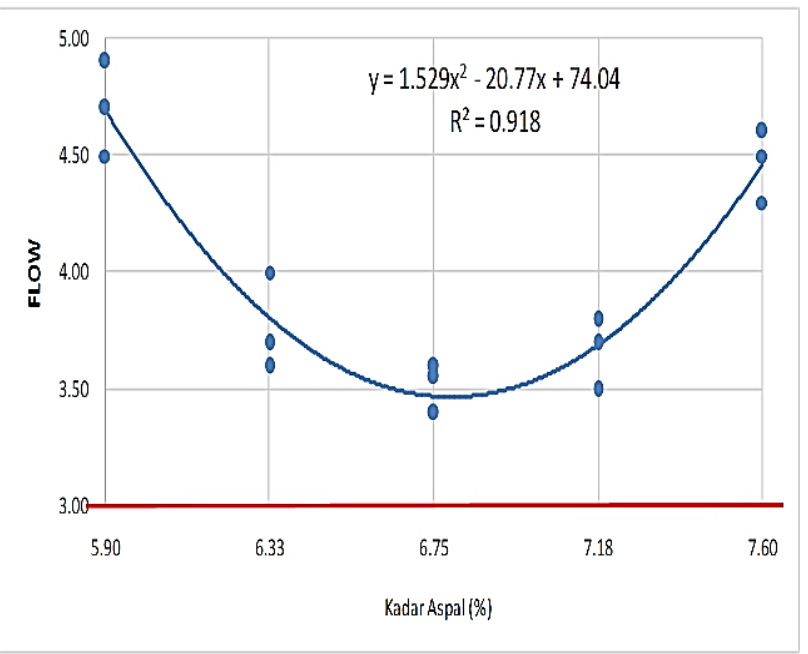

Gambar 7. Grafik flow gradasi senjang

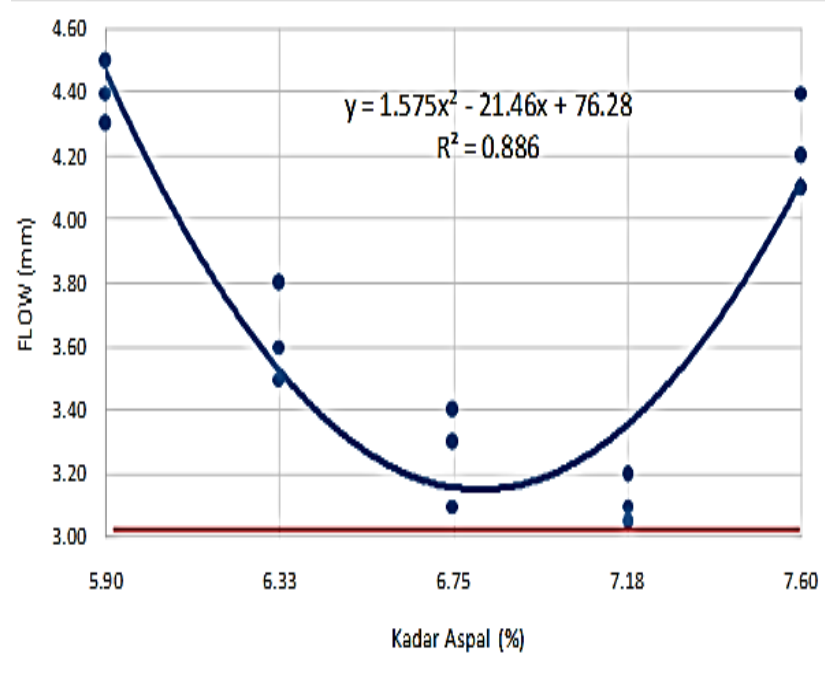

Gambar 8. Grafik flow gradasi semi senjang

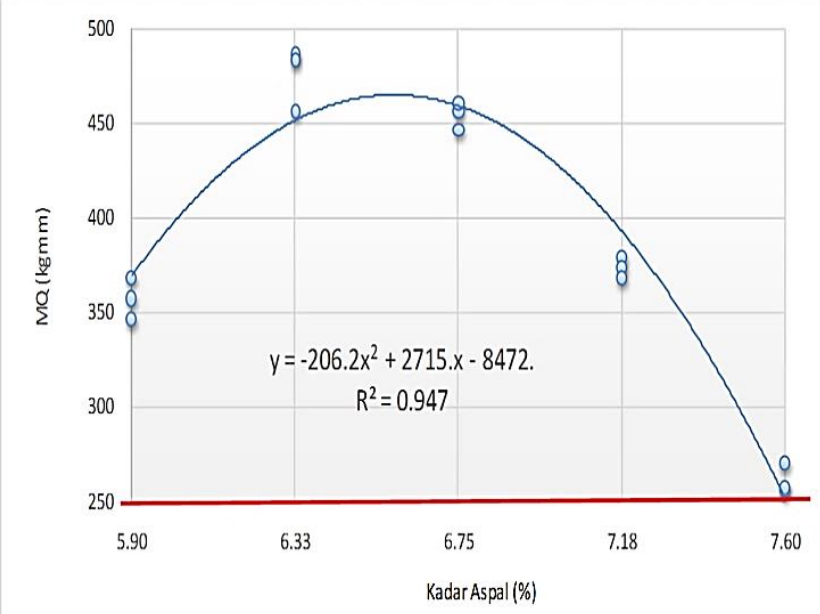

Gambar 9. Grafik MQ gradasi senjang

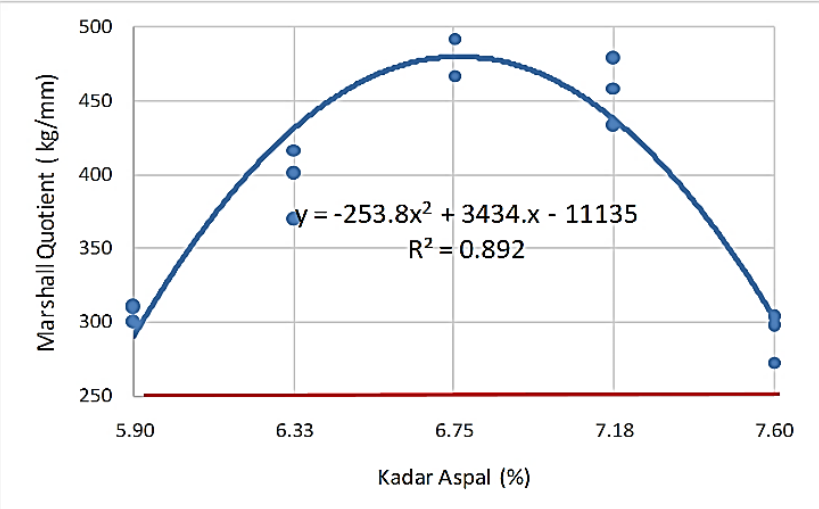

Gambar 10. Grafik MQ gradasi semi senjang

e. Analisis terhadap VMA (Void in Mineral
Aggregate)

Dengan menggunakan kadar Aspal 5,90\% - 7,60\% diperoleh nilai VMA antara 18,03 - 20,66 untuk gradasi senjang dan 18,14 - 20,74 untuk semi senjang. Semua nilai VMA dengan kadar Aspal 5,9\% - 7,6\% memenuhi persyaratan. Semakin besar kadar kadar aspal maka nilai VMA akan semakin tinggi juga, dikarenakan semakin berkurangnya volume rongga yang terdapat didalam butir agregat karena aspal yang ada di dalam campuran selain menyelimuti agregat, juga akan masuk mengisi rongga dalam agregat tersebut sehingga VMA meningkat. Grafik VMA gradasi senjang dan semi senjang dapat dilihat apda Gambar 11 dan 12. 


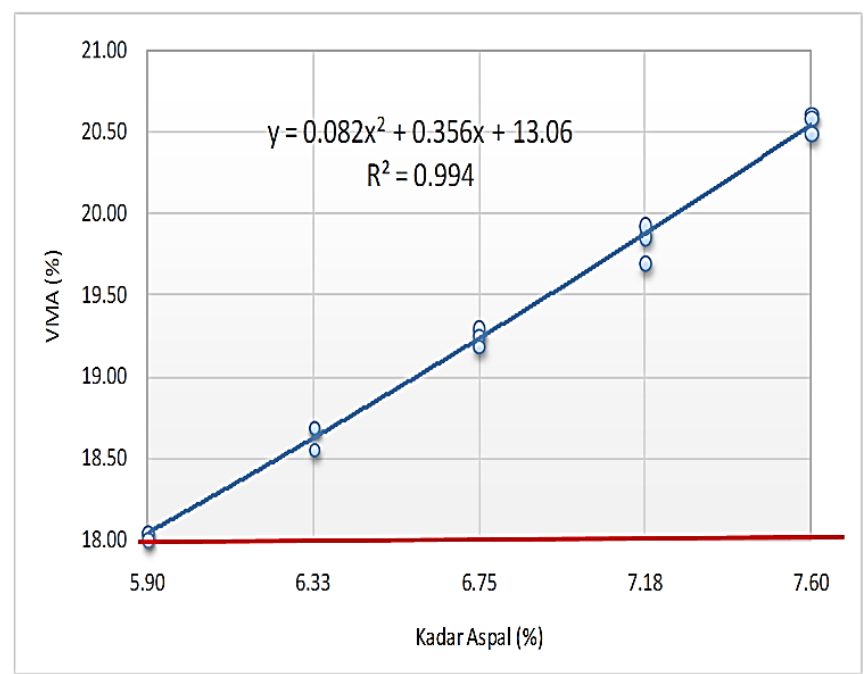

Gambar 11. Grafik VMA gradasi senjang

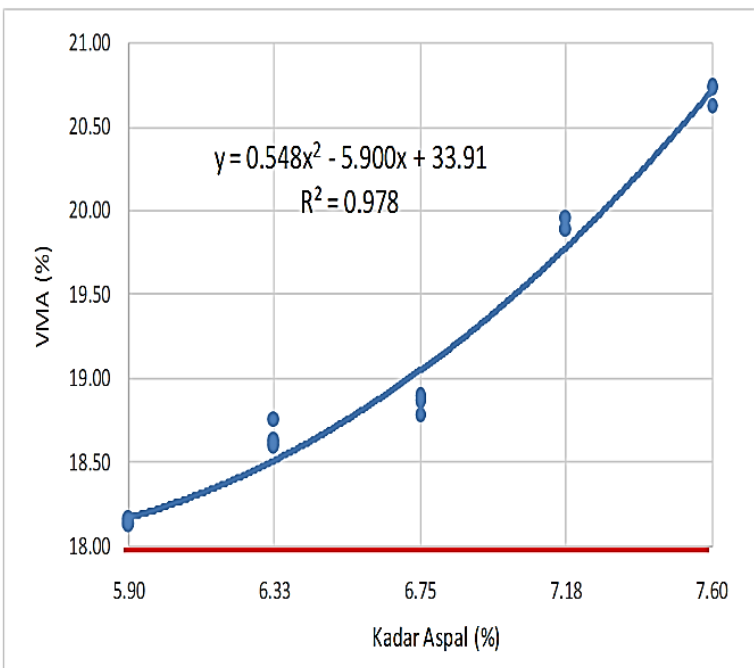

Gambar 12. Grafik VMA gradasi senjang

\section{f. VFB (Void Filled Bitument)}

Dengan menggunakan kadar Aspal 5,90\% - 7,60\% diperoleh nilai VFB antara $68.77-80.33 \%$ untuk gradasi senjang dan $68.88-80.37 \%$. Semua nilai VFB dengan kadar Aspal 5,9\%, 6,33\%, 6,75\%, 7,18, dan $7,6 \%$ memenuhi persyaratan. Semakin besar kadar kadar aspal maka nilai VFB akan semakin tinggi juga. Hal ini disebabkan karena karena pada saat pemadatan aspal lebih banyak mengikat agregat yang mengakibatkan volume rongga yang terisi aspal menjadi lebih banyak. Grafik VFB gradasi senjang dan semi senjang dapat dilihat pada Gambar 13 dan 14.

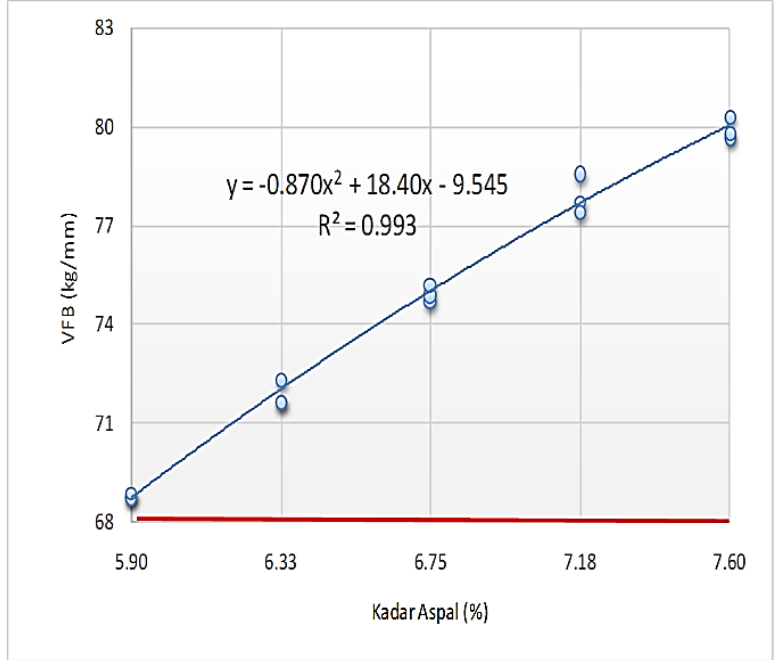

Gambar 13. Grafik VFB gradasi senjang

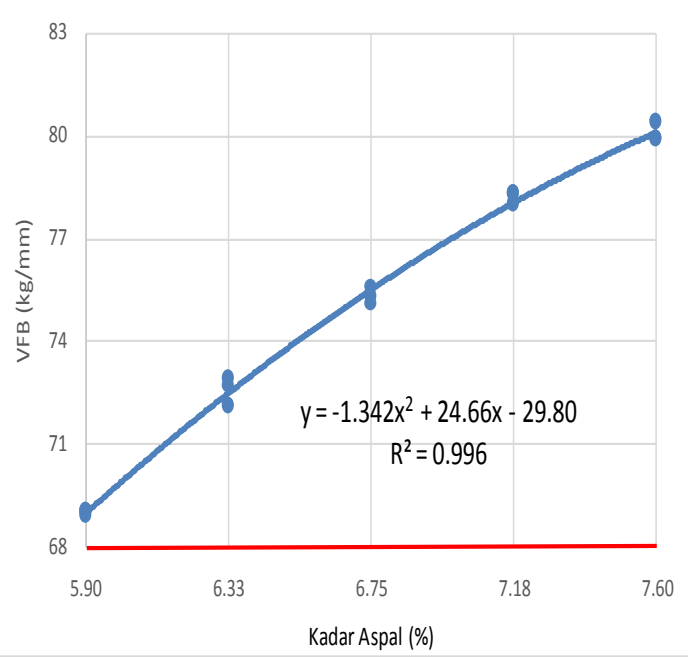

Gambar 14. Grafik VFB gradasi senjang

\section{Karakteristik Dan Analisis Marshall Immertion Campuran HRS-WC Gradasi Senjang dan Semi Senjang}

Untuk menganalisis data penelitian pada Marshall Immertion gradasi senjang dan semi senjang maka sebelumnya harus diketahui nilai kadar aspal optimum. Dari pengujian Marshall konvensional rentang kadar aspal 5,9\% - 7,6\% memenuhi semua kriteria atau karakteristik sehingga kadar aspal 7,6\% digunakan untuk pengujian Marshall Immersion. Kadar aspal 7,6\% memiliki paling kecil nilai VIM-nya karena LATASTON HRS-WC merupakan lapisan non-struktural yang berfungsi sebagai lapisan pelindung yang harus kedap air sehingga mampu melindungi lapisan yang ada dibawahnya maka kadar aspal yang tinggi akan mengisi rongga-rongga dalam campuran sehingga rongga yang tidak terisi aspal semakin berkurang.

Perhitungan Indeks Perendaman Marshall Immertion sebagai berikut: 
IP $=\frac{\text { StabilitasMarshallimmersion }}{\text { StabilitasMarshallKonvensioal }} \times 100 \%$

$$
\begin{aligned}
& =\frac{1107.88}{1181.74} \times 100 \% \\
& =93,75 \%
\end{aligned}
$$

Untuk hasil perhitungan selanjutnya dapat di lihat pada Tabel 5.

\begin{tabular}{|c|c|c|c|c|}
\hline \multicolumn{5}{|c|}{ WC gradasi senjang } \\
\hline $\begin{array}{c}\text { Benda } \\
\text { Uji }\end{array}$ & $\begin{array}{c}\text { Proporsi } \\
\text { aspal } \\
(\%)\end{array}$ & $\begin{array}{l}\text { Stabilitas } \\
\text { Marshall } \\
\text { Immertion } \\
\text { (kg) }\end{array}$ & $\begin{array}{c}\text { Stabilitas } \\
\text { Marshall } \\
\text { Konvensional } \\
\text { (kg) }\end{array}$ & $\begin{array}{l}\text { IP } \\
(\%)\end{array}$ \\
\hline 1 & 7.6 & 1107.88 & 1181.74 & 93.75 \\
\hline 2 & 7.6 & 1163.28 & 1218.67 & 95.45 \\
\hline 3 & 7.6 & 1052.49 & 1107.88 & 95.00 \\
\hline & ata & 1107.88 & 1169.43 & 94.73 \\
\hline
\end{tabular}

Tabel 5. Indeks perendaman untuk Lataston HRS -

Tabel 6. Indeks perendaman untuk Lataston HRS -

\begin{tabular}{|c|c|c|c|c|}
\hline $\begin{array}{c}\text { Benda } \\
\text { Uji }\end{array}$ & $\begin{array}{l}\text { Proporsi } \\
\text { aspal } \\
(\%)\end{array}$ & $\begin{array}{c}\text { Stabilitas } \\
\text { Marshall } \\
\text { Immertion } \\
(\mathrm{kg})\end{array}$ & $\begin{array}{c}\text { Stabilitas } \\
\text { Marshall } \\
\text { Konvensional } \\
(\mathbf{k g})\end{array}$ & $\begin{array}{l}\text { IP } \\
(\%)\end{array}$ \\
\hline 1 & & & 1274.06 & 98 \\
\hline 2 & & & & 96.92 \\
\hline 3 & 1.6 & & & 96.97 \\
\hline \multicolumn{2}{|c|}{ ata-rata } & 1200.21 & 1230.98 & 97.48 \\
\hline
\end{tabular}
WC gradasi semi senjang

Marshall Immersion adalah salah satu pengujian untuk melihat durabilitas (ketahanan terhadap beban dan pengaruh suhu ) atau keawetan suatu campuran, hasil dari pengujian ini adalah rasio stabilitas. Rasio tersebut membandingkan stabilitas dari benda uji Marshall setelah direndam dalam suhu 60 C dalam waterbath selama 24 jam terhadap stabilitas benda uji marshall dengan perendaman 30 menit yang biasa disebut indeks perendaman (IP) atau indeks kekuatan sisa ( IKS ).

Dari hasil pengujian Marshall Immertion diperoleh nilai rata-rata untuk indeks perendaman yaitu 94,73 untuk gradasi senjang dan 97,48 untuk semi senjang. Berdasarkan nilai tersebut dapat disimpulkan bahwa perkerasan jalan yang menggunakan Liquid Asbuton untuk Lataston HRS - WC dapat tahan terhadap suhu dan lamanya perendaman dalam air.

\section{KESIMPULAN}

Karakteristik agregat yang berasal dari Desa Buntao' Kecamata Buntao' Kabupaten Toraja utara untuk campuran Lataston HRS-WC bergradasi senjang dan semi senjang memenuhi standar. Komposisi campuran Lataston HRS-WC Gradasi senjang yaitu agregat kasar 25,83\%, agregat halus 59,66\%, filler $6,91 \%$, dan aspal 7,6\%, sedangkan untuk Lataston HRS-WC Gradasi semi senjang yaitu agregat kasar $19,47 \%$, agregat halus $66,20 \%$, filler $6,73 \%$ dan aspal 7,6\%. Nilai karakteristik Marshall campuran Lataston HRS-WC gradasi senjang dan gradasi semi senjang telah memenuhi standar. Dengan menggunakan kadar aspal optimum 7,6\% untuk Marshall Immertion diperoleh Indeks Perendaman atau Indeks Kekuatan sisa (IKS) 94,73\% untuk Lataston HRS -WC Senjang dan 97,48 \% untuk Lataston HRS -WC Semi Senjang, yang artinya campuran tahan terhadap suhu, lamanya perendaman dan terendam air yang menngunakan agregat dari Desa Buntao' Kabupaten Toraja Utara.

\section{DAFTAR PUSTAKA}

[1] "SNI 03-1968-1990." [Online]. Available: https://www.scribd.com/doc/38071047/SNI-031968-1990.

[2] C. Kamba and R. Rachman, "Marshall Characteristics Test On Hot Rolled Sheet Base Combine Using Nickel Slag For Half Gap Graded," vol. 5, no. 3, p. 6, 2018.

[3] "Kinerja Campuran Hot Rolled Sheet-wearing Course (Hrs-wc) Dengan Filler Abu Ampas Tebu - Neliti." [Online]. Available: https://www.neliti.com/publications/217437/kinerj a-campuran-hot-rolled-sheet-wearing-coursehrs-wc-dengan-filler-abu-ampas.

[4] "Kinerja Modulus Resilien dan Deformasi Permanen Dari Campuran Lataston Gradasi Senjang (HRS-WC) Dengan Bahan Aspal Modifikasi Starbit E-55 | Sinuhaji | Journal of Civil Engineering." [Online]. Available: http://journals.itb.ac.id/index.php/jts/article/view/9 485.

[5] "Kajian Perbedaan Kinerja Campuran Beraspal Panas Antara Jenis Lapis Tipis Aspal BetonLapis Aus (Hrs-Wc) Bergradasi Senjang Dengan Yang Bergradasi Semi Senjang | Hermanus | Jurnal Sipil Statik." [Online]. Available: https://ejournal.unsrat.ac.id/index.php/jss/article/ view/8207.

[6] "Studi Perilaku Campuran LatastoN (HRS-WC) Dengan 'Limbah Karet Ban Luar' Sebagai Bahan Pengganti Sebagian Aspal | Putra Kiswara | Media Teknik Sipil." [Online]. Available: http://ejournal.umm.ac.id/index.php/jmts/article/vi ew/2037.

[7] "Campuran Hot Rolled Sheet (HRS) dengan Material Piropilit Sebagai Filler yang Tahan Hujan Asam | Ambarwati | Rekayasa Sipil." [Online].Available:https://rekayasasipil.ub.ac.id/in dex.php/rs/article/view/136.

[8] "Spesifikasi Umum Bina Marga Divisi 62010 Perkerasan Aspal." [Online]. Available: https://www.scribd.com/doc/52889551/Spesifikas i-Umum-Bina-Marga-Divisi-6-2010-Perk-ErasAn-Aspal. 